\title{
Factor VIII prophylactic therapy reduces neurological complications in patients with Hemophilia A
}

\author{
Terapia profilática com Fator VIII reduz complicações neurológicas em paciente com \\ Hemofilia A
}

José Marcelino Aragão FERNANDES1,2, Francisco de Assis Aquino GONDIM³, Antônia Maria Negreiro DIAS², Rosângela de Albuquerque RIBEIRO², Luiz Ivando Pires FERREIRA FILHO², Vicente de Paulo Teixeira PINTO'

\begin{abstract}
Background: Bleeding in hemophiliacs can cause complications in the central and peripheral nervous system (CNS and PNS). The incidence of intracranial hemorrhage has reduced after the introduction of prophylactic treatment with factor VIII or IX, but the benefits of this therapy have not yet been evaluated on PNS complications. Objective: The aim of this study was to determine the prevalence of neurological complications in hemophiliacs and verify the effect of prophylactic therapy in these patients, including PNS disorders. Methods: We retrospectively evaluated the prevalence of CNS and PNS disorders caused by bleeding in hemophiliacs seen at the Hemocentro Regional Norte, Ceará, Brazil, from 1992 to 2018, and we compared the incidence in different periods (before and after the introduction of prophylactic treatment in 2011). Results: Of 75 hemophilia A patients evaluated (4.61/100.000 population), 13.3\% ( $n=10)$ had either CNS $(n=5)$ or PNS $(n=5)$ disorders secondary to bleeding. Patients submitted to factor VIII replacement prophylactic therapy were less likely to have CNS events: from 1992 to 2011, 5 of 63 patients had CNS disease, while from 2011 to 2018, there were no new cases $(p=0.0181$ ). From 2011 to 2018, 5 PNS events occurred in patients without prophylactic therapy, whereas none occurred in those covered by prophylactic therapy (5/20 versus $0 / 29, p=0.0081)$. Conclusions: The prevalence of neurological complications in hemophiliacs in our cohort is similar to other studies. Similar to CNS, prophylactic therapy also reduces the risk of PNS complications. This is the first report in the literature showing this benefit.
\end{abstract}

Keywords: Hemophilia A; Intracranial Hemorrhages; Peripheral Nervous System Diseases.

\section{RESUMO}

Antecedentes: O sangramento em hemofílicos causa complicações no sistema nervoso central e periférico (SNC e SNP). A incidência de hemorragia intracraniana diminuiu após a introdução da profilaxia com fator VIII ou IX, entretanto esse benefício ainda não foi avaliado no SNP. Objetivo: O objetivo deste estudo foi determinar a prevalência de complicações neurológicas em hemofílicos, verificando o efeito da terapia profilática também no SNP. Métodos: Avaliamos retrospectivamente a prevalência de complicações neurológicas causadas por sangramentos em hemofílicos atendidos no Hemocentro Regional Norte, Ceará, Brasil, de 1992 a 2018, comparando a incidência em diferentes períodos (antes e depois da introdução do tratamento profilático em 2011). Resultados: Foram avaliados 75 pacientes com hemofilia A (4,61/100 mil habitantes). Deles, $13,3 \%(n=10)$ tinham distúrbios do SNC $(n=5)$ ou do SNP $(n=5)$ secundários a hemorragias. Os pacientes submetidos à terapia profilática com fator VIII apresentaram menor probabilidade de eventos do SNC: de 1992 a 2011, cinco de 63 pacientes apresentaram hemorragia no SNC, enquanto de 2011 a 2018 não ocorreram novos casos ( $p=0,0181$ ). De 2011 a 2018, cinco eventos no SNP ocorreram entre pacientes sem terapia profilática, e nenhum ocorreu entre aqueles cobertos pela profilaxia $(5 / 20 \times 0 / 29, p=0,0081)$. Conclusões: A prevalência de complicações neurológicas em hemofílicos em nossa coorte é similar à de outros estudos. Assim como no SNC, a terapia profilática também reduz o risco de complicações no SNP. Este é o primeiro relato na literatura a mostrar esse benefício.

Palavras-chave: Hemofilia A; Hemorragias Intracranianas; Doenças do Sistema Nervoso Periférico.

\footnotetext{
'Universidade Federal do Ceará, Programa de Pós-Graduação em Ciências da Saúde, Sobral CE, Brazil.

${ }^{2}$ Centro de Hematologia e Hemoterapia do Ceará, Fortaleza CE, Brazil.

${ }^{3}$ Universidade Federal do Ceará, Departamento de Medicina Interna, Fortaleza CE, Brazil.

JMAF (D) https://orcid.org/0000-0001-7083-907X; FAAG (D) https://orcid.org/0000-0002-8957-5796; AMND (D) https://orcid.org/0000-0001-8456-1355; RAB (D) https://orcid.org/0000-0002-3637-9791; LIPFF (D) https://orcid.org/0000-0001-7774-8576; VPTP (D) https://orcid.org/0000-0002-8785-2171

Correspondence: José Marcelino Aragão Fernandes; Email:jmarcelinoaf@gmail.com.

Conflict of interest: There is no conflict of interest to declare.

Authors' contributions: JMAF, FAAG, VPTP: conception and design of the study; JMAF, AMND: performed the research; JMAF, Dias AMND, RAD, LIPFF: patient management/data acquisition; JAMF, FAAG, VPTP: performed data analysis; JMAF, FAAG, VPTP: wrote the manuscript; JMAF, FAAG, VPTP, AMND, RAR, LIPFF: approved the final manuscript.
}

Received on October 15, 2020; Received in its final form on December 16, 2020; Accepted on January 09, 2021. 


\section{INTRODUCTION}

Hemophilia is an X-linked hereditary coagulopathy characterized by deficiency or abnormality in functioning of factor VIII (hemophilia A) or IX (hemophilia B). Hemophiliacs are prone to a variety of serious bleeding complications, including hemarthrosis, intramuscular bleeding and hemorrhagic CNS disease ${ }^{1}$. Although hemarthrosis is the most common, intracranial hemorrhage (ICH) is certainly responsible for most bleeding-related deaths ${ }^{2}$.

Neurological abnormalities caused by bleeding in hemophiliacs may include disorders of the central and peripheral nervous system (CNS and PNS). Intracranial bleeding in hemophilia patients can be caused by head trauma or spontaneously, and encompass intracerebral bleeding, intraventricular hemorrhages, acute/chronic subdural hematoma $(\mathrm{SDH})$, and subarachnoid hemorrhage $(\mathrm{SAH})^{3}$. Spinal epidural hematomas are rare but a potential cause of severe neurological dysfunction ${ }^{4}$. Epidemiological studies have estimated prevalence of ICH to be $3.5-4 \%$, but this prevalence may be underestimated because some conditions are asymptomatic/mild, with spontaneous resolution².

The PNS can be affected in hemophiliacs primarily by compressive neuropathy, but mononeuropathy multiplex and myopathy have also been described ${ }^{5,6}$. Hematomas cause focal neuropathy, either from direct injury or from compartment syndrome ${ }^{7.89}$. In rare situations, hematomas can grow wild, and form a fibrous capsule that develops into a hemophilic pseudotumor (HPT) and may compress nerves ${ }^{9,10}$. The most commonly reported neuropathy involves the femoral nerve, usually as a direct consequence of hematomas in the iliopsoas muscle ${ }^{11,12}$. Other reported neuropathies involve the ulnar, median, sciatic, and peroneal nerves ${ }^{11,13,14}$. Peripheral neuropathies have been described in several clinical series from centers devoted to the treatment of hemophilia, with incidence ranging from $4.7-14.9 \%^{7,8}$.

Factor VIII replacement prophylaxis three times a week is the gold standard treatment of severe hemophilia. Some studies have shown the reduction in joint sequelae and intracranial bleeding in hemophiliacs undergoing prophylactic treatment ${ }^{1,15}$, but there are no reports in the literature of these benefits in PNS complications.

The aim of this study was to evaluate the prevalence and clinical features of neurological disorders caused by bleeding in hemophiliacs seen at a tertiary center, verifying the impact of factor VIII prophylactic treatment on these complications, including peripheral nerve injury. Part of this study was reported in abstract form elsewhere ${ }^{16}$.

\section{METHODS}

We reviewed the medical records of all hemophiliacs seen at the Blood Disorder Treatment Center located at the city of
Sobral, Ceará, Brazil, from 1992 to 12/2018. All patients with signs and symptoms of neurological disease were invited for a clinical interview and neurological exam, which was conducted. For patients we could not reach because they were either deceased or unable to attend the interview, their medical were records evaluated and neurological findings were also reported. We recorded all patients with signs and/or symptoms of CNS disease, including evidence of CNS disease documented by head computed tomography (CT), who had active evidence of bleeding or sequela. Patients with PNS disorders were only included if they had an altered neurological exam due to a bleeding lesion in the territory of a peripheral nerve documented by ultrasound (US) or CT imaging. In addition to imaging, electrophysiological testing (nerve conduction study and electromyography) was required to confirm nerve damage. For electromyography (EMG), a dose of factor VIII was given before the test, according to the Brazilian hemophilia management protocol. A US was also used to confirm ulnar nerve compression due to severe elbow arthropathy (resulting from recurrent hemarthrosis).

The first author (JMA Fernandes) has been working as a consultant neurologist for the Hemocentro Regional Norte since 2011 and personally conducted the neurological work-up for all neurological complaints during this period. Therefore, much the study functioned as a prospective study conducted by a single neurologist, increasing the strength of the evaluation.

The data was collected in a standardized form and included demographic factors, clinical history, general and neurological exam, and laboratory, imaging, and neurophysiological tests. Neurophysiological testing was similar to a protocol we have previously used ${ }^{17,18}$.

This study was approved by the IRB from the Centro de Hematologia e Hemoterapia do Ceará, in the city of Fortaleza, state of Ceará, Brazil (Protocol 2.979.266), including authorization for conducting EMG testing.

Descriptive statistics (mean+SEM) was initially employed to describe the results and we subsequently used $t$ test and Fisher exact test to compare the differences among the different groups. The differences were statistically significant when $\mathrm{p}<0.05$.

\section{RESULTS}

Data from 75 hemophiliacs were collected and 49, 14, and 12 had severe, moderate, and mild forms of hemophilia, respectively. All of them suffered from hemophilia A. Since the Hemocentro Regional Norte is the only center for the treatment of patients in the northern part of Ceará, we can estimate that the prevalence of hemophilia, and especially hemophilia $\mathrm{A}$ in this area is 1 patient/21675 inhabitants or 4.61 hemophiliacs/100.000 inhabitants (approximately 9.2 hemophilia A patients/100,000 male inhabitants). 
Of the 75 patients with hemophilia A in our series, $13.3 \%$ $(n=10)$ had CNS $(n=5)$ or PNS disorders $(n=5)$ due to bleeding (Tables 1 and 2, and Figures 1 and 2). One of the patients with PNS disorders suffered from bilateral lesions of the femoral nerve, acquired at different times, raising the number of PNS events to six. Therefore, the prevalence of either CNS or PNS disorders was $6.7 \%$. There were no bleeding or complications related to electromyography exams. Patients with CNS disease (intracranial bleeding) had their neurological events at a significantly earlier age than patients with PNS disorders: $12.6 \pm 6.4$ versus $32.5 \pm 5$ years $(\mathrm{p}<0.05)$. The group formed by patients with all types of neurological disorders (CNS and

Table 1. Demographic and imaging findings in persons with hemophilia A and central nervous system disease.

\begin{tabular}{ccccccc}
\hline$\#$ & Age $^{\text {a }}$ & Age $^{\mathrm{b}}$ & Disease subtype & Head trauma & Treatment & Outcome \\
\hline 1 & 19 & 19 & $\begin{array}{c}\text { Lacute frontal SDH (headache \& } \\
\text { seizure) }\end{array}$ & Yes & FVIII repl. & No sequelae \\
2 & 13 & 3 & R parietal SDH & Yes & FVIII repl. & Behavior disorder \& epilepsy \\
3 & 21 & 3 & $\begin{array}{c}\text { L temporo-parietal intracerebral } \\
\text { hemorrhage }\end{array}$ & Yes & Clot drainage/FVIII repl. & Epilepsy, L III nerve palsy \\
4 & 23 & 3 & Chronic L fronto-parietal SDH & Yes & None & Epilepsy, motor aphasia, R \\
hemiparesis
\end{tabular}

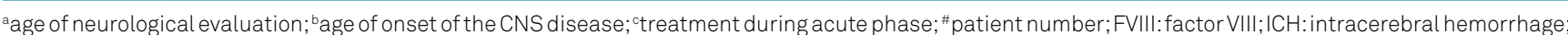
repl: replacement; R: right; L: left.

Table 2. Demographic and imaging findings in persons with hemophilia A and peripheral nervous system disease.

\begin{tabular}{|c|c|c|c|c|c|c|}
\hline \# & Age $^{a}$ & $\mathrm{Age}^{\mathrm{b}}$ & Disease subtype & Nerve $^{c}$ & Clinical features/EMG & Treatment ${ }^{\mathrm{d}}$ outcome \\
\hline 1 & 29 & 29 & $\begin{array}{l}\text { HPT, traumatic thigh } \\
\text { hematoma }\end{array}$ & R sciatic & $\begin{array}{l}\text { Paresthesias: thigh/lat leg } \\
\varnothing \text { Sup peroneal; 'sural SNAP }\end{array}$ & $\begin{array}{c}\text { FVIII repl; persistent sensory } \\
\text { changes }\end{array}$ \\
\hline 2 & 47 & 47 & R elbow artropathy & Rulnar & $\begin{array}{l}\text { Hypoesthesia \& weakness } \\
\varnothing \text { dorsal ulnarl; "ulnar SNAP }\end{array}$ & $\begin{array}{c}\text { FVIII repl; Lateral epicondylitis; } \\
\text { persistent sensory changes \& } \\
\text { minor weakness }\end{array}$ \\
\hline \multirow{2}{*}{3} & 40 & 42 & R IP hematoma (2015) & R femoral & Thigh hypoesthesia, ø bil KJ & \multirow{2}{*}{$\begin{array}{l}\text { FVIII repl; Also hepatitis C+; } \\
\text { persistent sensory changes }\end{array}$} \\
\hline & 42 & 42 & LIP hematoma (2017) & L femoral & EMG: øsaphenous; denervation & \\
\hline 4 & 16 & 16 & $\begin{array}{l}\text { Hematoma (iliac fossa), } \\
\text { traumatic }\end{array}$ & L femoral & $\begin{array}{l}\text { Thigh hypoesthesia, } \varnothing \mathrm{KJ} \\
\text { EMG: } \varnothing \text { saphenous; denervation }\end{array}$ & $\begin{array}{c}\text { FVIII repl; Persistent sensory } \\
\text { changes }\end{array}$ \\
\hline 5 & 37 & 22 & LIP hematoma & L femoral & $\begin{array}{l}\text { Thigh hypoesthesia, } \varnothing \mathrm{KJ} \\
\text { EMG: } \varnothing \text { saphenous; denervation }\end{array}$ & $\begin{array}{c}\text { FVIII repl; Persisent sensory } \\
\text { changes }\end{array}$ \\
\hline
\end{tabular}

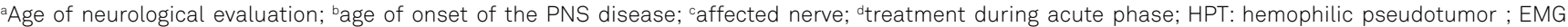
Electromyography; SNAP: sensory action nerve potential; \#: patient number; $\varnothing$ : absent; FVIII: Factor VIII; Bil: bilateral; IP: iliopsoas; KJ: knee jerk; R: right; L: left; repl: replacement.

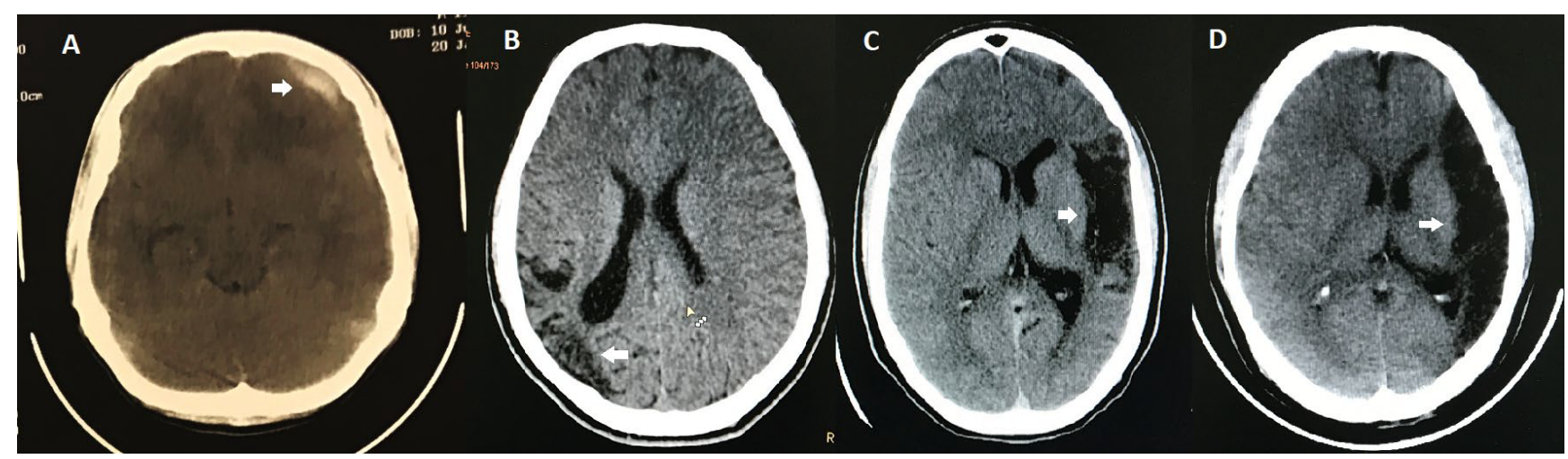

Figure 1. Imaging (computerized tomography) findings of the patients with hemophilia A and central nervous system disorders. A. (Case 1): Left frontal acute subdural hematoma. B. (Case 2): Residual (chronic) findings of a right parietal traumatic subdural hematoma. C. (Case 3): Residual (chronic) findings post evacuation of a severe left traumatic temporo-parietal contusion with uncal herniation. D (Case 4): Residual (chronic) findings of a severe left hemisphere traumatic subdural hematoma. Note: Case 5 had spontaneous subarachnoid hemorrhage confirmed by computerized tomography, but the image was not available. 

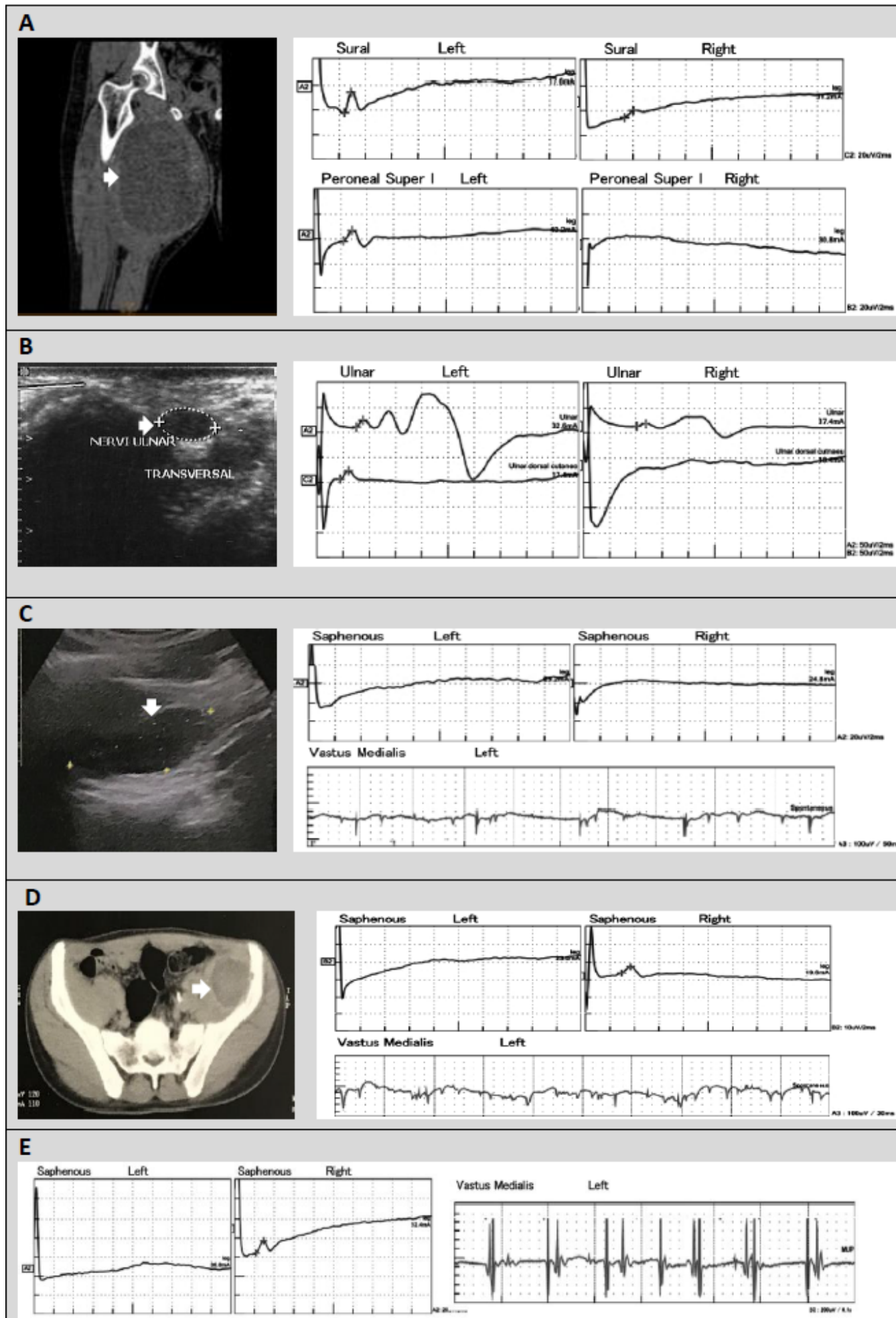

Figure 2. Imaging (ultrasonography and computerized tomography demonstrating hematoma, left side) and neurophysiological findings (right side) of the patients with hemophilia A and peripheral nervous system disorders. A (Case 1): Right thigh computerized tomography shows the presence of a hemophilic pseudotumor (arrow) with right sciatic nerve injury, i.e., reduction of the amplitude of the right sural sensitive action nerve potential and absence of the superficial peroneal sensory response. $\mathrm{B}$ (Case 2): Right elbow ultrasonography reveals thickening of the ulnar nerve (arrow) in a patient with hemophilic arthropathy at the elbow associated and a reduction in the amplitude of the right ulnar sensitive action nerve potential (top record) and absence of the right dorsal ulnar response (bottom record). C (Case 3): Left inguinal ultrasonography demonstrates hematoma of left iliopsoas (arrow) and absence of bilateral saphenous sensitive action nerve potential and acute denervation of the left vastus medialis muscle. D (Case 4): Pelvic computerized tomography reveals left iliac hematoma (arrow) and absence of the left saphenous sensitive action nerve potential and acute denervation (positive waves) in the left vastus medialis muscle. E (Case 5): Absence of the left saphenous SNAP and chronic denervation (polyphasic muscle unit action potentials with incomplete recruitment) in the left vastus medialis muscle. 
PNS) is older than the patients without neurological disorders: $31.7 \pm 11.5$ versus $21.3 \pm 14.28$ ( $\mathrm{p}<0.05$ ). Of all patients with neurological complications, nine had severe hemophilia A and one had a moderate form. Four out of five CNS lesions and four out of six PNS lesions had a history of trauma. Positive HIV serology and presence of factor VIII inhibitor occurred only in one case of CNS and PNS, respectively.

As can be seen in Table 1 and Figure 1, three patients had subdural hematoma, one intracerebral hemorrhage, and one subarachnoid hemorrhage. Overall, the outcome of those conditions was good, although one patient underwent intracerebral hemorrhage drainage (patient \#3) and three were left with epilepsy or behavior disorders.

As can be seen in Table 2 and Figure 2, the most affected nerve was the femoral nerve $(n=3)$. One of the patients (\#3), had bilateral hematomas at 2 different occasions, which raised the total number of peripheral neuropathies to 6. One patient with HPT in the right thigh (caused by a chronic traumatic hematoma), associated with right sciatic neuropathy and the last patient had tardive right ulnar neuropathy related to right elbow hemophilic arthropathy. Most of the patients had predominant residual sensory involvement, although patients 2, 3, and 4 had more significant motor involvement. The mechanism of nerve injury was entrapment due to the presence of blood clot in most of the cases. None of our cases were under prophylactic treatment (replacement of factor VIII concentrate three times a week) at the time they had the neurological injury.

We conducted Fisher exact test to evaluate whether central or peripheral nervous system disorders were more prevalent prior to the establishment of factor VIII replacement prophylactic therapy (implemented in 2011). Patients submitted to factor VIII replacement prophylactic therapy were less likely to have CNS events (Table 3): from 1992 to 2011, 5 of the 63 patients had CNS disease, while from 2011 to 2018, there were no new cases $(\mathrm{p}=0.0181)$.

At first, there seemed to be no difference in the incidence of PNS disorder before and after prophylaxis introduction (Table 3 ): $1 / 63$ versus $4 / 75$ ( $p=0.2193$ ). Notwithstanding, when we analyzed the patients after availability of prophylactic therapy (since 2011), there was a significant reduction in PNS in treated versus untreated patients (Table 3): among 49 patients with severe hemophilia (eligible for prophylactic therapy), 29 patients started prophylaxis while 20 stayed on symptomatic treatment (on demand). From 2011 to 2018, 5 PNS events occurred among patients without prophylactic therapy, while none occurred among those covered by prophylactic therapy $(\mathrm{p}=0.0081)$.

\section{DISCUSSION}

Hemophilia is a rare coagulopathy, with a worldwide prevalence ranging from 1-9/100.000 inhabitants ${ }^{1}$. In this study,
Table 3. Factor III replacement prophylactic therapy ${ }^{a}$ versus neurological disease.

\begin{tabular}{|c|c|c|c|}
\hline \multicolumn{4}{|c|}{ CNS disease in hemophiliacs prior and after prophylaxis era } \\
\hline & $\begin{array}{l}\text { CNS } \\
\text { disease }\end{array}$ & $\begin{array}{l}\text { No CNS } \\
\text { disease }\end{array}$ & Total \\
\hline $\begin{array}{l}\text { Prior to prophylaxis } \\
\text { era (1992-2011) }\end{array}$ & 5 & 58 & 63 \\
\hline After prophylaxis era (2011-2018) & 0 & 75 & 75 \\
\hline \multicolumn{4}{|l|}{$p<0.05(0.0181)$} \\
\hline \multicolumn{4}{|c|}{ PNS disease in hemophiliacs prior and after prophylaxis era } \\
\hline & $\begin{array}{c}\text { PNS } \\
\text { disease }\end{array}$ & $\begin{array}{l}\text { No PNS } \\
\text { disease }\end{array}$ & Total \\
\hline Prior prophylaxis era (1992-2011) & 1 & 62 & 63 \\
\hline Prophylaxis era (2011-2018) & 5 & 70 & 75 \\
\hline \multicolumn{4}{|l|}{$p>0.05(0.2193)$} \\
\hline \multicolumn{4}{|c|}{ PNS disease in hemophiliacs in the prophylaxis era $(2011-2018)^{b}$} \\
\hline Treatment modality & $\begin{array}{l}\text { PNS } \\
\text { disease }\end{array}$ & $\begin{array}{c}\text { Free-PNS } \\
\text { disease }\end{array}$ & Total \\
\hline Prophylaxis & 0 & 29 & 29 \\
\hline Symptomatic (on demand) & 5 & 15 & 20 \\
\hline$p<0.05(0.0081)$ & & & \\
\hline
\end{tabular}

aFactor VIII 25-30 U/kg 3x/week; bincluded only patients with severe hemophilia A; CNS: central nervous system; PNS: peripheral nervous system.

we found a prevalence of hemophilia and more specifically of type A hemophilia, of approximately 4.6 cases/100.000 inhabitants, similar to the prevalence of 5 and 4.6 cases of hemophilia $\mathrm{A} / 100.000$ inhabitants previously reported in Brazil and Northeast Brazil, respectively ${ }^{19}$.

The prevalence of CNS bleeding in hemophiliacs has been described to be between 2.4 to $12 \%^{7,20-27}$. PNS complications range from 4.7 to $19 \%^{6-8,28,29}$. In our study, the prevalence was 6.7\% for both CNS and PNS diseases.

Intracranial bleeding is the most common neurological disorder in hemophiliacs reported in the literature. Intracerebral hemorrhage and subdural hematoma were the most common subtypes ${ }^{7,21-27}$. We also found that those subtypes were the most common in our study. Four of our patients with CNS disorders had a history of head trauma. The majority of the studies reported a positive relationship between head trauma and $\mathrm{ICH}^{7,21,22,24,25}$. Only one patient, who was HIV-positive, had a spontaneous SAH. Two studies showed a relationship between HIV infection and spontaneous hemorrhage ${ }^{22,30}$. None of our patients died, but three patients had late sequelae, especially epilepsy.

The prevalence of PNS disorders is certainly less studied, but there are some clinical series describing that the femoral is the most commonly affected nerve $e^{6-8,28,29}$, similar to our study. The other neuropathies diagnosed in our study were ulnar neuropathy due to severe elbow arthropathy and sciatic neuropathy due to HPT in the thigh. A total of 5 patients with 6 neuropathies were diagnosed. Four lesions were related to limb trauma. 
Even with $90 \%$ of the neurological lesions affecting hemophiliacs with severe disease, we did not find a significant relationship between hemophilia severity and the presence of neurological disease ( $\mathrm{p}=0.1502$ ), probably due to the small sample (type II error). We only found two studies that also did not establish a relationship with hemophilia severity, while another revealed a positive association ${ }^{15,23,26}$.

None of our cases with central or peripheral nervous system disease were on factor VIII replacement prophylactic therapy at the time of the neurological event. Since prophylaxis was introduced in Brazil in 2011 and all our ICH cases occurred prior to this period, we believe that the prophylactic therapy is associated with a risk reduction of ICH in our center. Recent studies have demonstrated that prophylactic therapy is linked to ICH reduction in hemophiliacs ${ }^{15,25,31}$.

Regarding compressive neuropathies, in our study, 5 events (in 4 patients) occurred after prophylaxis was introduced in 2011. Considering that prophylactic treatment is indicated only for patients with severe hemophilia, from 2011 to 2018, we had 49 severe hemophiliacs eligible for prophylactic treatment. Of these, 29 started prophylaxis and 20 remained in symptomatic therapy (on demand). Among the latter group, five neuropathies occurred up to 2018, while none occurred in the prophylaxis group (Table 3). Thus, our findings showed a positive effect of prophylactic therapy $(p<0.05$, Fisher exact test) in reducing peripheral nerve involvement in hemophiliacs. There are no similar reports in the literature, but only reports of risk reduction of arthropathy and CNS disease.

We believe that cases of PNS disease were underdiagnosed in the pre-prophylaxis era, especially because our center had a neurologist consulting hemophiliacs only after 2011.

The current mean age of patients with neurological diseases was significantly higher than the rest of the patients without neurological disease. We believe that this finding also reflects improvement in the management of hemophiliacs in Brazil in the last two decades, with the introduction of home care and prophylactic therapies.

In summary, ICH and femoral neuropathy are the main CNS and PNS diseases in hemophiliacs, mostly caused by trauma. To our knowledge, our study is the first to simultaneously evaluate the prevalence of CNS and PNS complications prior to and after prophylactic therapy. Despite a relatively small sample, this is the first report of an improvement of PNS complications with prophylactic therapy. It reveals that prophylactic therapy, in addition to decreasing the risk of ICH and arthropathy, can also decrease the risk of PNS lesions.

\section{ACKNOWLEDGMENTS}

We thank Dr. Augusto Carioca from the Fortaleza University for his statistical advice.
1. Berntorp E, Shapiro AD. Modern haemophilia care. Lancet. 2012 Apr;379(9824):1447-56. https://doi.org/10.1016/S01406736(11)61139-2

2. Bladen M, Main E, Khair K, Hubert N, Koutoumanou E, Liesner R. The incidence, risk and functional outcomes of intracranial haemorrhage in children with inherited bleeding disorders at one haemophilia center. Haemophilia. 2016 Jul;22(4):556-63. https://doi.org/10.1111/hae.12938

3. Blanden M, Khair K, Liesner R, Main E. Long-term consequences of intracranial haemorrhage in children with haemophilia. Haemophilia. 2009 Jan;15(1):184-92. https://doi.org/10.1111/j.13652516.2008.01815.x

4. Choudhary AK, Jha B. Imaging findings in spinal subarachnoid hemorrhage in patient with hemophilia A: an unusual cause for back pain. Emerg Radiol. 2011 Apr;18(2):173-5. https://doi.org/10.1007/ s10140-010-0916-5

5. De Faria CR, De Melo-Souza SE, Pinheiro ED. Haemophilic neuromyopathy. J Neurol Neurosurg Psychiatry. 1979 Jul;42(7):6005. https://doi.org/10.1136/jnnp.42.7.600

6. Chang CW, Shen MC. Mononeuropathy multiplex in hemophilia: an electrophysiologic assessment. Eur Neurol. $1998 \mathrm{Jul} ; 40(1): 15-8$. https://doi.org/10.1159/000007949

7. Gaffarpoor M, Sharifian R, Mehrabi F, Salehi M. Neurologic complications in hemophilia: a study in 214 cases. Acta Med Iran. 2001;39(4):182-4.

8. Saraf SK, Singh OP, Singh VP. Peripheral nerve complications in hemophilia. J Assoc Physicians India. 2003 Feb;51:167-9.
9. Donaldson J; Goddard N. Compartment syndrome in patients with haemophilia.J Orthop. 2015 Dec;12(4):237-41. https://doi. org/10.1016/j.jor.2015.05.007

10. Panotopoulos J, Ay C, Trieb K, Funovics PT, Stockhammer V, Lang S et al. Surgical treatment of the haemophilic pseudotumour: A single centre experience. Int Orthop. 2012 Oct;36(10):2157-62. https://doi. org/10.1007/s00264-012-1593-7

11. Zhai J, Weng X, Zhang B, Liu Y, Gao P, Bian YY. Surgical treatment for hemophilic pseudotumor. Twenty-three Cases with an Average Follow-up of 5 Years. J Bone Joint Surg Am. 2017 Jun;99(11):947-53. https://doi.org/10.2106/JBJS.16.01299

12. Rodriguez-Merchan EC. Peripheral nerve injuries in haemophilia. Blood Transfus. 2014 Jan;12 Suppl 1(Suppl 1):s313-8. https://doi. org/10.2450/2012.0111-12

13. Balkan C, Kavakli K, Karapinar D. Iliopsoas haemorrhage in patients with haemophilia: results from one centre. Haemophilia. 2005 Sep;11(5):463-7. https://doi.org/10.1111/j.1365-2516.2005.01123.x

14. Mortazavi SMJ, Gilbert RS, Gilbert MS. Cubital tunnel syndrome in patients with haemophilia. Haemophilia. 2010 Mar;16(2):333-8. https://doi.org/10.1111/j.1365-2516.2009.02141.x

15. Andersson NG, Auerswald G, Barnes C, Carcao M, Dunn AL, Fijnvandraat $\mathrm{K}$, et al. Intracranial haemorrhage in children and adolescents with severe haemophilia A or B - the impact of prophylactic treatment. Br J Haematol. 2017 Oct;179(2):298-307. https://doi.org/10.1111/bjh.14844 
16. Fernandes JMA, Gondim FAA, Pinto VPT, Dias AMN. Prevalence of Central and Peripheral Nervous System Disorders in Hemophiliacs from the Northern Part of the State of Ceará, Brazil. In: Annals of the 2019 PNS Annual Meeting, 22-29 June, Genoa, Italy [accessed on Oct 05, 2020]. Available at: https://www.pnsociety.com/files/ Meetings/2019\%20Meeting\%20Genoa/Abstracts/Sunday\%20 23\%20June\%20TOC\%20and\%20posters(1).pdf.

17. Gondim FAA, Oliveira GR, Teles BCV, Souza MHLP, Braga LLBC, Messias EL. Clinical and electrodiagnostic findings in patients with peripheral neuropathy and inflammatory bowel disease. Inflamm Bowel Dis. 2015 Sep;21(9):2123-9. https://doi.org/10.1097/MIB.0000000000000459

18. Gondim FAA, Oliveira GR, Teles BCV, Aquino PS, Brasil EF, Carvalho $A M$, et al. A case-control study of the prevalence of neurological diseases in inflammatory bowel disease (IBD). Arq Neuro-Psiquiatr. 2015 Feb;73(2):119-24. https://doi.org/10.1590/0004-282X20140223

19. Ferreira AA, Leite ICG, Bustamante-Teixeira MT, Guerra MR. Hemophilia A in Brazil - epidemiology and treatment developments. J Blood Med. 2014;5:175-84. https://doi.org/10.2147/JBM.S68234

20. Lütschg J, Vassella F. Neurological complications in hemophilia. Acta Paediatr Scand. 1981 Mar;70(2):235-41. https://doi. org/10.1111/j.1651-2227.1981.tb05548.x

21. Eyster ME, Gill FM, Blatt PM, Hilgartner MW, Ballard JO, Kinney TR. Central nervous system bleeding in hemophiliacs. Blood. 1978 Jun;51(6):1179-88. https://doi.org/10.1182/blood.V51.6.1179. bloodjournal5161179

22. Antunes SV, Vicari P, Cavalheiro S, Bordin O. Intracranial haemorrhage among a population of haemophilic patients in Brazil. Haemophilia. 2003 Sep;9(5):573-7. https://doi.org/10.1046/j.13652516.2003.00789.x

23. Stieltjes N, Calvez T, Demiguel V, Torchet MF, Briquel ME, Fressinaud $E$, et al. Intracranial haemorrhages in French haemophilia patients (1991-2001): clinical presentation, management and prognosis factors for death. Haemophilia. 2005 Sep;11(5):452-8. https://doi. org/10.1111/j.1365-2516.2005.01090.x

24. Zanon E, lorio A, Rocino A, Artoni A, Santoro R, Tagliaferri A, et al. Intracranial haemorrhage in the Italian population of haemophilia patients with and without inhibitors. Haemophilia. 2012 Jan;18(1):39-45. https://doi.org/10.1111/j.1365-2516.2011.02611.x

25. Hu Q, Zhang A, Liu AG, Wang S, Wang Y, Zhang L. A retrospective analysis of intracranial hemorrhage in children with hemophilia A. Curr Med Sci. 2018 Oct;38(5):875-9. https://doi.org/10.1007/s11596018-1956-4

26. Nelson Jr MD, Maeder MA, Usner D, Mitchell WG, Fenstermacher MJ, Wilson DA, et al. Prevalence and incidence of intracranial haemorrhage in a population of children with haemophilia. Haemophilia. 1999 Sep;5(5):306-12. https://doi.org/10.1046/j.13652516.1999.00338.x

27. Chalmers EA, Alamelu J, Collins PW, Mathias M, Payne J, Richards M, et al. Intracranial haemorrhage in children with inherited bleeding disorders in the UK 2003-2015: A national cohort study. Haemophilia. 2018 Jul;24(4):641-7. https://doi.org/10.1111/hae.13461

28. Ehrmann L, Lechner K, Mamoli B, Novotny C, Kos K. Peripheral nerve lesions in haemophilia. J Neurol. 1981 Jun;225(3):175-82. https://doi. org/10.1007/BF00313746

29. Katz SG, Nelson IW, Atkins RM, Duthie RB. Peripheral nerve lesions in hemophilia. J Bone Joint Surg Am. 1991 Aug;73(7):1016-9.

30. Nuss R, Soucie JM, Evatt B; Changes in the occurrence of and risk factors for hemophilia-associated intracranial hemorrhage. Am J Hematol. 2001 Sep;68(1):37-42. https://doi.org/10.1002/ajh.1146

31. Witmer C, Presley R, Kulkarni R, Soucie JM, Manno CS, Raffini L. Associations between intracranial haemorrhage and prescribed prophylaxis in a large cohort of haemophilia patients in the United States. Br J Haematol. 2011 Jan;152(2):211-6. https://doi. org/10.1111/j.1365-2141.2010.08469.x 